\title{
Phytoprotection
}

\section{Assessing and Improving the Safety of Introductions for Biological Control}

\section{Keith R. Hopper}

Volume 79, numéro 4, 1998

OECD Workshop - Sustainable Pest Management, Safe Utilization of New Organisms in Biological Control. Montréal, Québec, Canada. September 27-30, 1998.

Atelier de l'OCDE - Gestion durable des ennemis des cultures, Utilisation sécuritaire de nouveaux organismes de lutte biologique. Montréal, Québec, Canada. 27-30 Septembre 1998.

URI : https://id.erudit.org/iderudit/706163ar

DOI : https://doi.org/10.7202/706163ar

Aller au sommaire du numéro

Éditeur(s)

Société de protection des plantes du Québec (SPPQ)l

ISSN

0031-9511 (imprimé)

1710-1603 (numérique)

Découvrir la revue

Citer cet article

Hopper, K. R. (1998). Assessing and Improving the Safety of Introductions for Biological Control. Phytoprotection, 79(4), 84-93.

https://doi.org/10.7202/706163ar d'utilisation que vous pouvez consulter en ligne. 


\title{
Assessing and Improving the Safety of Introductions for Biological Control
}

\author{
Keith R. Hopper
}

Beneficial Insect Introduction Research Unit, Agricultural Research Service, United States Department of Agriculture, and Department of Entomology and Applied Ecology, University of Delaware, Newark, Delaware 19713, USA

\section{ABSTRACT}

Introduced natural enemies may have direct and indirect effects on non-target species. Methods for evaluating impacts on non-target species are available from literature on evaluating effects on target species, although these are most apt for measuring direct impacts. Despite the availability of methods, there are essentially no solid data concerning impacts on non-target species of arthropods introduced for biological control, even though there is a long history of concerns and current controversy about the risk of such impacts. Lack of evidence concerning nontarget impacts reflects in part lack of research, but it also suggests that nontarget impacts of biological control are much less than from other human activities. More effective quarantine of unwanted species, better screening of intentional introductions of horticultural species, and improved alternative pest management strategies should reduce the need for introductions. Improved efficacy for each introduction should reduce the number of introductions needed. Improved screening of host, habitat, phenology and climate ranges, together with better understanding of their evolution and more information on dynamics of non-target species, should reduce risk per introduction. Critics and practitioners of biological control introductions should work together to generate the knowledge needed for analysis of the risks and benefits.

\section{INTRODUCTION}

Introduction of exotic species that become pests is an increasing problem for agriculture, health, and the environment (OTA-US-Congress 1993; van Lenteren 1995). Biological control by introduction of exotic natural enemies is one way of reducing pest abundance and thus impact (OTA-US-Congress 1995; Tisdell 1990). The concept is simple: introduced (or even native) organisms sometimes become pests because they lack natural enemies sufficient to keep their abundances below damaging levels. Thus, introduction of appropriate natural enemies should reduce target species abundance below pest level. Although the success of establishment and subsequent control might be improved (Hopper 1996), such introductions have proved a cost-efficient and non-toxic method for solving pest problems (Tisdell 1990; Greathead 1995). However, controversy has arisen concerning the risk that introduced natural enemies will harm non-target species (Howarth 1991; Simberloff and Stiling 1996). Here, I will first review the possible impacts of natural enemy introductions and methods for detecting such impacts. Then in the light of this information, I will discuss the evidence adduced concerning whether unwanted impacts have occurred or are likely to occur. I will then briefly discuss problems with weighing risks versus benefits of natural enemy introductions. Finally, I will review research needs and 
regulatory approaches to avoiding nontarget impacts of natural enemy introductions. I will emphasize arthropods introduced to control arthropods, merely because this is the sort of introduction most familiar to me. However, where appropriate I will also discuss arthropods introduced to control plants. I will neither treat pathogens introduced to control arthropods or plants nor antagonists introduced to control plant pathogens. Such introductions raise different sorts of questions, which given limitations on space and, more importantly, in my knowledge, I cannot address here.

\section{POTENTIAL IMPACTS OF INTRODUCED NATURAL ENEMIES}

\section{Establishment}

Introduced natural enemies may fail to establish and thus not have any longterm impact, although even species that ultimately fail to establish may have local, short-term impact on target and non-target species.

\section{Impacts on target species}

Introduced natural enemies are expected to attack target species, although errors in taxonomy have sometimes prevented this impact (Delucchi et al. 1976). Attack on a target may not reduce its abundance at all, let alone reduce it below damaging levels. Indeed only about half of introductions that establish against arthropod pests provide useful control (Greathead 1995). The rate of useful control is higher for introductions of arthropods against weeds (Julien et al. 1984), perhaps because of greater screening before introduction (McEvoy 1996). In most cases where biological control introductions are considered, reduction of the target species is considered an unmitigated benefit. However, in some cases, reduction of the target species may be unwanted by some people, giving rise to conflicts of interest. A well known case of such conflict involved Echium plantagineum: in Australia, this plant was considered a weed by graziers because of its toxicity to sheep and beneficial by bee-keepers because it was a source of nectar (Delfosse 1985). Tamarisk provides another example: in the southwestern United States, this introduced tree competes for water with native and forage plants (Fornasari 1997), but also provides habitat for an endangered bird (Brown 1992).

\section{Direct impacts on non-target species}

Introduced natural enemies may attack or compete with non-target species. Whether they do so depends on the genetic limits to their biology. Host or prey range is the most obvious aspect of natural enemy biology determining the likelihood of impact on non-target species and has been the trait most used in this regard (McEvoy 1996). Whether or not non-target species are included in the host or prey range of phytophagous or entomophagous arthropods introduced for biological control depends on (1) the physiology and behavior of plant-herbivore, host-parasitoid, or prey-predator interactions; (2) the climatic and habitat distributions of host/ prey and natural enemy; and (3) genetic variation in host/prey and natural enemy (Harris and McEvoy 1995; Strand and Obrycki 1996).

As with target species, natural enemy attack or competition may not reduce abundance of non-target species at all, let alone greatly reduce abundances or cause extinctions. The magnitude of changes in abundance will depend on the amount, timing, spatial distribution, and density-dependence of ensuing mortality, as well as on other aspects of non-target species population dynamics (e.g., age schedule of natality and mortality and their densitydependence in the absence of attack by or competition with the introduced natural enemy) and the ability of the non-target species to develop, through phenotypic or genetic plasticity, physiological or behavioral resistance to natural enemy attack or competition. Abundances of non-target species may not change at all because of compensatory changes in age structure, physiology, or behavior. However, such compensatory changes themselves may be regarded as unwanted impacts. 
Indirect impacts on non-target species

If a natural enemy reduces abundance or causes other changes in non-target species, this may in turn reduce abundance or cause other changes in yet other non-target species that rely on the originally affected non-target species (e.g., as prey, host, defender, dispersal agent, or habitat). The tendency for such effects to propagate through ecological communities depends on the tightness of trophic links and other interactions (Simberloff 1992), which in turn depends on the amount that reduction in one species is compensated by increases in its ecological homologues, and on the phenotypic and genetic plasticity of non-target species. Ecologists have divergent views on the structure of ecological communities, the extremes being that communities are clockwork, where any perturbation will affect the whole mechanism, versus communities are like a pile of seashells, where removing one will affect the local neighborhood, but not the whole pile. This divergence leads to very different ideas about likelihood of nontarget impacts and methods for their assessment.

\section{Impact dynamics and a priori arguments}

Because nature and human society are dynamic, the classification of an outcome may change over time. Natural enemies, targets, and non-targets may evolve, and societies may change judgements concerning wanted and unwanted impacts.

Several a priori arguments have been put forward concerning the inherent risks of biological control introductions. Three aspects of biological control introductions which are considered advantages for target impacts may be considered disadvantages when nontarget impacts are considered or when society changes judgement about the target: (1) introduced natural enemies are relatively permanent additions to the environment; (2) they can spread by themselves; and ( 3 ) they can evolve in the new environment. It is worth noting that, for impact on the target species, the third trait is useful when the original and new environments do not sufficiently match or when the target species can evolve defenses. Two aspects of biological control introductions are not considered advantages for target impacts, but could be risks for target impacts: (1) natural enemies of abundant pests may be maintained at high levels and thus affect non-target species regardless of non-target species densities; and (2) attack by natural enemies of abundant pests may combine with competition from those pests to harm non-target species.

\section{METHODS FOR DETECTING NON-TARGET IMPACTS}

Impacts of introduced natural enemies on non-target species can be detected using the same methods used for detecting impacts on target species (for review, see Luck et al. 1988). These techniques fall into three categories: (1) field surveys; (2) exclosure experiments; and (3) pre/post introduction experiments. Because of the resources involved, studies of impacts on nontarget species must be limited to the most likely candidates for such impacts.

\section{Field surveys}

Whether and how much introduced parasitoids parasitize non-target species can be determined by field collections of non-target hosts. Levels of parasitism can be measured by rearing, dissection, and analysis of various molecular markers (e.g., allozymes, DNA) (Menken and Ulenberg 1987). Whether and how much predators consume nontarget prey can be determined by field collections of predators and analyses of their gut contents. Gut content analysis with visual examination or molecular markers can be used to identify prey (Stuart and Greenstone 1990). Field labeling of prey with trace elements and subsequent detection with atomic absorption spectrometry can also reveal whether specific prey species are being consumed (Hopper 1991). Direct observation of field behavior of natural enemies can reveal levels of attack or competition. This approach is most easily applied with herbivores 
attacking plants, but can even be used with very small parasitoids (Heimpel et al. 1997). Depending on the spatiotemporal coverage of the data and the quality of sampling and analysis, such field surveys can supply (1) qualitative data on host range or quantitative data for correlation analyses; (2) life tables; (3) key-factor analysis; or (4) mathematical models to analyze natural enemy effects on population dynamics. Mathematical models are particular useful when based on data sets collected over space and time and including measurements of climate and habitat. Without experimental manipulations, field survey data can be difficult to translate into estimates of population level impacts. However, models developed from data collected in one set of places or times may successfully predict dynamics in another set of places or times. Such models may provide estimates of impact or lack thereof impossible to achieve with experimental manipulations because of the mobility of arthropod species.

\section{Exclosure experiments}

Arthropods can be excluded from habitat patches using physical barriers (e.g., cages) or chemical barriers (repellents or toxins), and the dynamics of host plants, host, or prey can then be observed in the absence versus presence of phytophages or entomophages. Cage experiments have problems with microclimatic differences, blocked immigration/emigration, and delineation of which excluded natural enemies were responsible for differences in host/prey abundances. On the other hand, truly selective toxins are often difficult to find. Some of these problems can be addressed with techniques like open cages to control for modification of microclimate, traps to capture potential emigrants, and different size meshes to exclude various size classes of natural enemies. Thus, exclosure experiments have been found to be powerful tools for testing the impact of biological control agents on target weeds (McEvoy and Rudd 1993) and insects (Hopper et al. 1995), especially when used in conjunction with analyses of field survey data (Hopper 1996) and other manipulations (McEvoy and Rudd 1993). These techniques should be just as powerful for tests of impacts on non-target species.

\section{Pre- versus post-introduction experiments}

Properly designed introductions of natural enemies can be used to test the impact of introduced natural enemies on non-target species. To ensure sufficient statistical power, non-target species abundances and other characteristics of interest should be measured for a sufficiently long period over a sufficiently large area both before and after natural enemy introduction. Replicated introductions across diverse habitats with measurement of non-target species abundances and other characteristics for several seasons both before and after natural enemy introduction would provide the most powerful tests with this approach.

Unfortunately, such studies have rarely been carried out for impact on target species, let alone for impact on nontarget species. Natural enemy introductions are grand experiments, but biological control researchers have rarely taken advantage of such introductions to test hypotheses about how to maximize impact of introductions on target species, let alone how to minimize impact on non-target species. Researchers concerned about the risks of biological control introductions have been just as remiss at not working with biological control researchers on testing for impacts on non-target species.

\section{EVIDENCE CONCERNING IMPACTS ON NON-TARGET SPECIES}

Above I discussed possible impacts on non-target species; the probability of such impacts is extremely difficult to evaluate, given the current state of ecological theory and its thin experimental foundation. Unfortunately, possible impact and actual evidence for impact have sometimes not been carefully separated in discussions about the risk of biological control introductions. Despite a long history of concern about impacts of introduced natural enemies 
on non-target species (Perkins 1897; Zimmerman 1948; Zimmerman 1958) and heightened debate over the issue during the last 15 years (Howarth 1983; Funasaki et al. 1988; Lai 1988; Howarth 1991; Lockwood 1993; Carruthers and Onsager 1993; Simberloff and Stiling 1996), there appear to be no rigorous studies showing that arthropods intentionally introduced for biological control have reduced abundances, let alone caused extinctions, of native non-target species.

Several studies document attack on native non-target species, but almost none have tested even local changes in abundances. Rhinocyllus conicus, a weevil introduced to control exotic thistles (Carduus spp.) in North America, has been found to attack native Cirsium spp. in North America (Turner et al. 1987; Louda et al. 1997), but the impacts of $R$. conicus on Cirsium spp. abundances has not been tested. $M i$ croctonus aethiopodes, a parasitoid introduced to control an exotic weevil (Sitona discoideus) in New Zealand, has been found to attack native weevils (Barratt 1996), but the impacts of $M$. aethiopodes on native weevil abundances has not been tested. Abundance of two species out of seven native coccinellid species did decline with increased abundance of Coccinella septempunctata, an introduced coccinellid (Elliot et al. 1996), but this study was restricted to 3 agricultural fields at each of 3 locations and does not necessarily reflect changes in abundance regionally or in non-agricultural habitats. Furthermore, this study raises the issue of what should be the baseline for analyzing impacts on non-target species. Should it be the abundances of nontarget species just before introductions, even if these abundances may themselves be the result of previous human disturbances, e.g., destruction of bison herds and conversion of prairie to crops?

Of the putative cases of non-target impacts cited by Howarth 1991 and by Simberloff and Stiling 1996 (two of the most prominent publications warning of the risk of biological control introductions), none of those concerning reductions in abundance caused by arthropods introduced for biological control are supported by data, let alone rigorous experimentation. Although it is true that lack of evidence of nontarget impacts indicates more the lack of rigorous studies than lack of impact (Howarth 1991; Simberloff 1992), several observations suggest that nontarget impacts from arthropods introduced for biological control have not been of remotely the same order of magnitude as those from other human activities. First, legally endangered species tend to be frequently monitored so that impact on them is likely to be quickly seen. Second, most plant and arthropod species are endangered because they occupy a limited habitat which is in danger of destruction (Simberloff 1993), rather than because they have low innate capacities for increase and thus are extremely vulnerable to natural enemies. Indeed, many arthropods have rather high capacities for increase which suggests that predation and parasitism may not have the sort of impact expected from predation on vertebrate species. Third, large impacts on native environments usually are readily observable and have been documented for introductions of domestic animals on islands. Indeed, the major factor causing extinctions of Hawaiian insects appears to have been habitat destruction by pigs, cattle, goats, sheep, and humans, and here the evidence is concrete in the form of hectares of native forest destroyed (Zimmerman 1948). Unfortunately, the impacts of habitat destruction and of introductions of arthropods for biological control in Hawaii cannot be separated. However, the evidence on host ranges of introduced arthropods suggests that attack let alone impact on abundances has been minor (Funasaki et al. 1988).

Nonetheless, natural enemies introduced for biological control do sometimes reduce target abundance (although almost never to extinction) and so could in principal also reduce nontarget abundance. Furthermore, accidentally introduced herbivores can have devasting effects on crops and other plants, and this is the reason for introducing entomophagous insects. Simberloff 1992 describes the impact of 
Cactoblastis cactorum on Opuntia spinosissima in Florida as an example of biological control run amok. However, this moth was accidentally introduced into the United States, probably in the horticultural trade (Pemberton 1995), so its impact in the United States should not be described as that of a biological control introduction. It is true that $C$. cactorum should not have been introduced into Caribbean, but this was done in 1957, well before concern about species extinctions had become widespread. However, why is $O$. spinosissima rare in the first place? I have been unable to find published literature on this question, but given the human development in south Florida, along the south coast of the United States, and throughout the Caribbean, it would seem that habitat destruction is a likely explanation. This raises the problem with assigning causes for extinction. If species has been made so rare by destruction of its habitat that any perturbation, say a lightning strike, could wipe out the remaining population, should one be concerned about the lightning strike or about the habitat destruction that reduced abundance to this level of vulnerability? Simberloff 1992 argues we study both proximate and ultimate causes of extinctions; however, others disagree (Soule 1983). Furthermore, conservation resources devoted to extremely vulnerable remnant populations are diverted from others where the same resources would be much more effective.

In summary, although there is limited evidence for attack on or competition with non-target species by arthropods introduced for biological control, few of the methods used for evaluating impacts of introduced natural enemies on target species have been applied to evaluating their impacts on non-target species.

\section{WEIGHING RISKS OF NON-TARGET IMPACTS AND BENEFITS OF INTRODUCTIONS}

Economic analyses have been done of the benefits to agriculture of arthropod introductions for biological control (Tisdell 1990; Greathead 1995). However, although the need for weighing the risks versus benefits of biological control introductions has been emphasized by critics and practioners alike (Howarth 1991; Carruthers and Onsager 1993; McEvoy 1996; Simberloff and Stiling 1996), quantitative risk analysis is extremely difficult because there is so little evidence on which to base estimates of the risks of biological control or comparisons of risks among various alternatives in managing pests. Such analyses are complicated for any form of pest management and especially complicated for biological control introductions. A major problem is defining criteria for what are good versus bad impacts. For example, biological control of a pest may reduce competitive suppression of other plants or insects which then become pests. Thus, although the target may no longer be a pest, the agroecosystem or nature reserve has gained nothing by such an introduction. On the other hand, competition from introduced natural enemies which reduces populations of native natural enemies may in some cases be useful when the native natural enemies themselves threaten rare species, especially if the native natural enemy densities have been inflated by previous human activity. Another problem is that risks and benefits are often unequally distributed among geographical regions and segments of society. Furthermore, decisions are made for political units, yet because of dispersal, introductions affect biogeographical units. Probably the greatest barrier to risk analysis is the lack of adequately predictive theory in population, community, and evolutionary ecology. This lack explains to a great extent the emphasis on host range screening as the major tool for determining whether introductions are advisable: at least one can make some attempt at measuring host range.

\section{AVOIDING NON-TARGET IMPACTS}

Given our current lack of knowledge con-cerning non-target impacts of 
biological control introductions, but assuming that the risk of such impacts should be reduced, what can be done? One can either reduce the number of introductions or reduce the risk per introduction.

The number of introductions can be reduced by decreasing the need for introductions or increasing the efficacy of each introduction. The need for biological control introductions can be reduced by decreasing the frequency of pest introductions or increasing the efficacy of native natural enemies and other strategies. Pest introductions can be decreased by better management of pest species overseas, more effective quarantine against accidental introductions, and better screening of intentional introductions, especially of horticultural species. The efficacy of native natural enemies could be improved by better landscape management. For example, integrated cropping systems may provide the key to management of the Russian wheat aphid, Diuraphis noxia, in the United States. Improvements in other strategies include (1) more effective and cheaper mycoherbicides and microbial insecticides, perhaps genetically engineered, (2) resistant crops, including trangenics, (3) better management of pesticide resistance, (4) new classes of more environmentally safe pesticides, and (5) education of vendors and consumers to accept cosmetic damage. However, genetically engineered pathogens and plants have also been criticized for potential non-target effects (Howarth 1991).

Fewer, more effective introductions could be achieved through field studies of target pest and natural enemy ecology in the area of pest origin to determine whether natural enemies are likely to provide effective control and which species are most likely to do this with minimum impact on non-target species. Retrospective analyses of past introductions could test whether host ranges have evolved and whether previous introductions are now affecting population dynamics of non-target species. More fundamental research is needed on mechanisms of control, attributes of natural enemies, and the rules of thumb about how to carry out introductions (e.g., climate matching, numbers to collect, numbers to release per site). Each natural enemy introduction should be designed to provide as much of this sort of information as possible. The results of these experiments should be embodied in mathematical models of colonization biology that can be tested in subsequent introductions. A caveat concerning fewer, more effective introductions is that several competing species with different host ranges may prevent any one from becoming too abundant and thus reduce likelihood of impact on non-target species (Harris 1990). This too could be tested in a variety of systems.

How can such research be done given the limited funding available? First, we need to convince decision makers (e.g., legislatures, private foundations, conservation groups) to provide more funding for this kind of research. The high rate of return on investment in biological control introductions (Tisdell 1990; Greathead 1995) suggests that decision makers might be convinced that this would be a worthwhile alternative to forgoing such introductions. Given the complexity of the problems involved, perhaps we should take a big-science approach (like the human genome project). Second, pure ecologists should work together with biological control researchers to leverage the maximum information from what are in fact large colonization experiments. Third, more coordination among agencies, universities, grower and conservation groups is needed. The Australian Cooperative Research Centers provide a good model for such coordination.

The potential non-target impact per natural enemy species introduced could be reduced by improved screening of host and habitat ranges, research on evolution of host and habitat ranges, and research on population dynamics of selected non-target species. Host range screening of phytophagous arthropods for biological control introductions is already well developed (McEvoy 1996). Host range screening of entomophagous arthropods proposed 
for introduction could be improved by screening based on phylogenetic and other similarities of target and nontarget species and biology of hostparasitoid/prey-predator interactions (Hopper 1995; Strand and Obrycki 1996). Much screening of both phytophagous and entomophagous candidates could be done in the area of origin, thus reducing costs for containment facilities. To improve impact on target species, candidates for biological control introductions have been selected for preadaptation to the phenology, habitat (e.g., vegetation type), and climate of the target species and region. However, to my knowledge, phenology, habitat and climate ranges have not been used to screen candidates to reduce non-target impacts. Yet one of the main objections to introduced natural enemies is that they may spread into habitats and climates where they are not wanted. Selection of species with restricted phenologies and narrow habitat or climate ranges would reduce risks of nontarget impacts. However, research is needed on the validity of climate matching and on the effects of habitat on mating, foraging, and oviposition. Research is also needed on the evolution of phenology and host, habitat and climate ranges in various taxomic and functional groups. Although the literature on host-parasitoid/prey-predator interactions provides some insights (Strand and Pech 1995), this is an active area of investigation which could benefit from the collaboration between basic and applied researchers. Laboratory selection experiments involving exposure to novel hosts can provide useful insights. However, as with selection for insecticide resistance, the genetic basis of responses to laboratory versus field selection may be very different (Roush and McKenzie 1987). Experiments on the mechanism of host/ prey specificity and its underlying genetic basis are crucial. Furthermore, retrospective analyses of the evolution of host ranges of previously introduced natural enemies are likely to prove very useful. This could involve common garden experiments with material from areas of origin and introduction, comparison of current with previously known host ranges, and analyses of museum collections. Lastly, research on population biology of selected nontarget species that introduced natural enemies might attack or compete with would provide information about sensitivity of non-target species to such interactions.

\section{CONCLUSIONS}

A call for more research from a researcher is not surprising, but in this case it is not pro forma. If we are to advance beyond debate about the potential risks of biological control introductions to an understanding of actual impacts and how to avoid them, it can only be through more research. It would be best if such research could be a collaboration between those concerned about non-target impacts and the practioners of biological control introductions. Often these have been same people (Turner et al. 1987; Diehl and McEvoy 1990; Harris 1990), and this blend of concerns is likely to contribute most to our knowledge.

\section{REFERENCES}

Barratt B. 1996. Biological control, is it environmentally safe? Forest and Bird November: 37- 41

Brown BT. 1992. Nesting chronology, density and habitat use of black-chinned hummingbirds along the Colorado River, Arizona. Journal of Field Ornithology 63: 393-506

Carruthers RI, Onsager JA. 1993. Perspective on the use of exotic natural enemies for biological control of pest grasshoppers (Orthoptera: Acrididae). Environmental Entomology 22: 885-903

Delfosse ES. 1985. CSIRO Division of Entomology submission to the inquiries into biological control of Echium plantagineum L. CSIRO Institute of Biological Resources, Canberra

Delucchi V, Rosen D, Schlinger EI. 1976. Relationship of systematics to biological control pp81-91. In CB Huffaker and PS Messenger eds. Theory and practice of biological control. Academic Press, New York 
Diehl J, McEvoy PB. 1990. Impact of cinnabar moth (Tyria jacobaeae) on Senecio trianularis, a non-target native plant in Oregon pp119-126. In ES Delfosse eds. Proceedings of the Seventh International Symposium on Biological Control of Weeds. Ministero dell'Agricoltura e delle Foreste and CSIRO, Rome

Elliot N, Kieckhefer R, Kauffman W. 1996. Effects of an invading coccinellid on native coccinellids in an agricultural landscape. Oecologia 105: 537-544

Fornasari L. 1997. Host specificity of Coniatus tamarisci (Coleoptera: Curculionidae) from France: Potential biological control agent of Tamarix spp in the United States. Environmental Entomology 42: 349-356

Funasaki GY, Lai P-Y, Nakahara LM, Beardsley JW, Ota AK. 1988. A review of biological control introductions in Hawaii: 1890-1985. Proceedings of the Hawaiian Entomological Society 28: 105-160

Greathead DJ. 1995. Benefits and risks of classical biological control pp53-63. In HMT Hokkanen and JM Lynch eds. Biological Control: Benefits and Risks. University Press, Cambridge

Harris P. 1990. Environmental impact of introduced biological control agents pp289-299. In M Mackauer, LE Ehler and $\mathrm{J}$ Roland eds. Critical issues in biological control. Intercept, Andover, UK

Harris P, McEvoy P. 1995. The predictability of insect host plant utilization from feeding tests and suggested improvements for screening weed biocontrol agents pp125-131. In ES Delfosse and RR Scott eds. Proceedings of the Eighth International Symposium on Biological Control of Weeds. DSIR and CSIRO, Canterbury, New Zealand

Heimpel GE, Rosenheim JA, Mangel M. 1997. Predation on adult Aphytis parasitoids in the field. Oecologia 110: $346-352$

Hopper KR. 1991. Ecological applications of elemental labeling: analysis of dispersal, density, mortality, and feeding. Southwestern Entomologist Supplement 14: 71-84

Hopper KR. 1995. Potential impacts on threatened and endangered insect species in the United States from introductions of parasitic Hymenoptera for the control of insect pests pp64-74. In HMT Hokkanen and JM Lynch eds. Biological Control: Benefits and Risks. University Press, Cambridge, UK

Hopper KR. 1996. Making biological control introductions more effective pp61-76. In JK Waage eds. Biological control introductions: opportunities for improved crop production. British Crop Protection Council Symposium Proceedings No. 67. British Crop Protection Council, Brighton, UK
Hopper KR, Aidara S, Agret S, Cabal J, Coutinot D, Dabire R, Lesieux C, Kirk G, Reichert S, Tronchetti F. 1995. Natural enemy impact on the abundance of Diuraphis noxia (Homoptera: Aphididae) in wheat in southern France. Environmental Entomology 24: 402-408

Howarth FG. 1983. Biological control: panacea or Pandora's box. Proceedings of the Hawaiian Entomological Society, 1980 24: $239-244$

Howarth FG. 1991. Environmental impacts of classical biological control. Annual Review of Entomology 36: 485-509

Julien MH, Kerr JD, Chan RR. 1984. Biological control of weeds: an evaluation. Protection Ecology 7: 3-25

Lai P-Y. 1988. Biological control: a positive point of view. Proceedings of the Hawaiian Entomological Society, 1986 28: 179-190

Lockwood JA. 1993. Environmental issues involved in biological control of rangeland grasshoppers (Orthoptera: Acrididae) with exotic agents. Environmental Entomology 22: 503-518

Louda SM, Kendall D, Connor J, Simberloff D. 1997. Ecological effects of an insect introduced for the biological control of weeds. Science 277: 1088-1090

Luck RF, Shepard BM, Kenmore PE. 1988. Experimental methods for evaluating arthropod natural enemies. Annual Review of Entomology 33: 367-391

McEvoy PB. 1996. Host specificity and biological pest control. Bioscience 46: 401-405

McEvoy PB, Rudd NT. 1993. Effects of vegetation disturbances on insect biological control of tansy ragwort, Senecio jacobaea. Ecological Applications 3: 682-698

Menken SBJ, Ulenberg SA. 1987. Biochemical characters in agricultural entomology. Agricultural Zoology 2: 305-360

OTA-US-Congress. 1993. Harmful non-indigenous species in the United States. OTA-F-565. U.S. Government Printing Office, Washington, DC

OTA-US-Congress. 1995. Biologically based technologies for pest control. OTA-ENV636. US Government Printing Office, Washington, DC

Pemberton RW. 1995. Cactoblastis cactorum (Lepidoptera: Pyralidae) in the United States: an immigrant biological control agent or an introduction of the nursery industry? American Entomologist 41: 230-232

Perkins RCL. 1897. The introduction of beneficial insects into the Hawaiian Islands. Nature 55: 499-500 
Roush RT, McKenzie JA. 1987. Ecological genetics of insecticide and acaricide resistance. Annual Review of Entomology 32: $361-380$

Simberloff D. 1992. Conservation of pristine habitats and unintended effects of biological control pp103-117. In WC Kauffman and JE Nechols eds. Selection criteria and ecological consequences of importing natural enemies. Entomological Society of America, Lanham, Maryland, USA

Simberloff D. 1993. The ecology of extinction. Acta Palaeontologica Polonica 38: 159-174

Simberloff D, Stiling P. 1996. How risky is biological control? Ecology 77: 1965-1974

Soule ME. 1983. What do we really know about extinction? pp111-124. In CM Schonewald-Cox, SM Chambers, B MacBryde and L Thomas eds. Genetics and Conservation: a Reference for Managing Wild Animal and Plant Populations. Benjamin/Cummings, Menlo Park, California

Strand MR, Obrycki JJ. 1996. Host specificity of insect parasitoids and predators. Bioscience 46: 422-429

Strand MR, Pech LL. 1995. Immunological basis for compatibility in parasitoid-host relationships. Annual Review of Entomology 40: 31-56
Stuart MK, Greenstone MH. 1990. Beyond ELISA: a rapid, sensitive, specific immunodot assay for identification of predator stomach contents. Annals of the Entomological Society of America 83: 1101 1107

Tisdell CA. 1990. Economic impact of biological control of weeds and insects pp301-316. In M Mackauer, LE Ehler and J Roland eds. Critical Issues in Biological Control. Intercept, Andover, Hants, UK

Turner CE, Pemberton RW, Rosenthal SS. 1987. Host utilization of native Cirsium thistles (Asteraceae) by the introduced weevil Rhinocyllus conicus (Coleoptera: Curculionidae) in California. Environmental Entomology 16: 111-115

van Lenteren JC. 1995. Frequency and consequences of insect invasions pp3043. In HMT Hokkanen and JM Lynch eds. Biological Control: Benefits and Risks. University Press, Cambridge, UK

Zimmerman EC. 1948. Insects of Hawaii, Vol. 1, Introduction. University of Hawaii Press, Honolulu

Zimmerman EC. 1958. Insects of Hawaii, Vol. 7, Macrolepidoptera. University of Hawaii Press, Honolulu 